\title{
Oral habit frequency of 7-15 years old homeless children
}

\author{
Nur Widya Damayanti*, Iwan Ahmad Musnamirwan*, Ratna Indriyanti* \\ *Department of Pedodontics Faculty Of Dentistry Universitas Padjadjaran
}

\begin{abstract}
Introduction: Oral habit is a bad habit that causes dental changes if habit are continued for long periods of time. Oral habit included digit sucking, lip sucking or biting, nail biting, mouth breathing. The purpose of study is to know the condition of oral habits in 7-15 years old homeless children undercare of Rumah Perlindungan Anak GANK (Generasi Anti Narkotika \& Kriminalitas). Methods: This study was a descriptive research by survey technique. The sample consisted of 46 children collected by total sampling. Data pertaining to the study was collected through interviews in form questionnaire and clinical examinations. Result: The result shows that $71,74 \%$ have oral habits, consisting of 18 boys (54,54 $\%$ ) and 15 girls (45,45\%), out of which 26,09\% homeless children have lip sucking or biting, 21,74\% have nail biting, 17,39\% have mouth breathing and 6,52 \% have thumb sucking habit. Conclusion: Oral habit frequencyvwere most performed in homeless children was lip sucking or biting.
\end{abstract}

Keywords: Oral habit, children, homeless

\section{INTRODUCTION}

According to Undang-Undang No.23 Year 2002, children were entitled to get proper health services and social insurances. This law also applies to street kids however most of them who are homeless do not benefit from the law even though they are considered as the next generation of the nation. The existence of street kids seems to have become a phenomenon in big cities. The phenomenon occurred due to the impact of rapid flow of urbanization and the development of the urban environment that promises success to the poor people. The economic crisis also caused the increases of number of street kids. Therefore, they are required to be able to make a living by begging, busking or becoming hawkers themselves. ${ }^{1,2}$
The duty of a child is just spending their time in school, but street kids eventually spending a lot of their time on the streets to make a living. ${ }^{3}$ They grow and develop with the background of street life which is often associated with poverty, mistreatment and lack of love and attention from their surrounding environment. ${ }^{4}$ The surrounding environment is considered as a factor that affect the psychological development process of children cognitively, socially and emotionally. Children who do not have a good surrounding environment might experiences psychological developmental disorders. Impaired psychological development can cause children to behave badly. Bad behavior can be shown by their oral habit. ${ }^{5}$ Oral habits is a bad habits that occurred in oral cavity and can cause interference with their teeth and surrounding tissue. Oral habits include 
thumb sucking, mouth breathing, sucking or biting their lips, pushing their tongue, biting their nails, pushing the frenulum and bruxism. ${ }^{6}$ Oral habits are temporary however it will develop according to the age of children. Oral habits which involved the contractions of the orofacial muscles in a long term, it might cause an imbalance of the orofacial muscles that interfere with bone growth, tooth malposition and dentofacial deformity. Several types of oral habits might cause also cause class II malocclusion. ${ }^{7,8}$

Glidasya research result (year 2006) of 96 children at Bandung Bahtera Foundation (Yayasan Bahteran Kota Bandung), which aims to determine the prevalence of oral habits in street kids aged 6-12 years old, 50\%of the street kids have oral habits with the most prevalence oral habit is thumb sucking around $21.74 \%$. The research proves that street kids at aged of 6-12 years old have bad habits (thumb sucking). The prevalence of thumb sucking will reach the peak prevalence rate in childhood and will decrease in adolescence, while nail biting will reach the peak prevalence rate in adolescence. Further research on the frequency of oral habits in adolescence still have no definitive data yet. ${ }^{9}$

Rumah Perlindungan Anak GANK is a foundation that works with social services with the aim of reducing the number of street kids in the Bandung. Fostered street children is a child who works around the Kiaracondong station (Stasiun Kiaracondong) dan crossroads around Antapani, Malabar, Samsat and Jalan Jakarta. Rumah Perlindunga Anak GANK has tutors who provide street kids with skills according to their interests. The skills provided do not make them leave their street life and they will still continue working on the streets to make their living for themselves and their family. Purpose of study is to know frequency of oral habits of homeless children with the aged of 7-15 years old in Rumah Perlindunga Anak GANK (Generasi Anti Narkotika dan Kriminalitas) in Bandung.

\section{METHODS}

This research is a descriptive study with a survey technique. The study population is street kids with the age of 7-15 years old at Rumah Perlindunga Anak GANK (Generasi Anti Narkotika dan Kriminalitas). Sampling is carried out by using total sampling techniques, which is the sampling technique by making all the members of the population as samples. The number of samples in the research is 46 children. Researches used the interview method through questionnaires and clinical examinations to determine the presence of oral habits in street kids. The questionnaire contains questions about the oral habit and various factors that cause the emergence of oral habit. Clinical examination is done by checking the oral condition of the respondent. The data obtained is collected and analyzed and presented in tables and diagrams.

\section{RESULTS}

The study was conducted at Rumah Perlindungan Anak GANK (Generasi Anti Narkotika dan Kriminalitas) in February 2012. Respondents are fostered street kids by Rumah Perlindungan Anak GANK with the age of 7-15 years old. A total

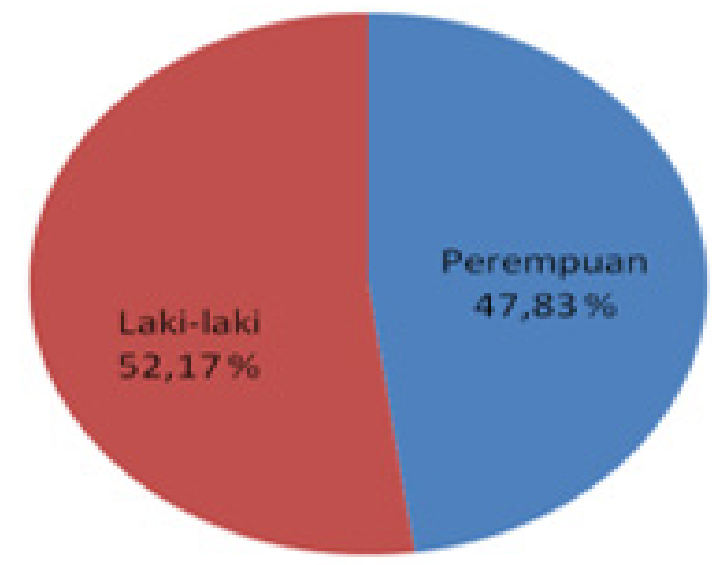

Gambar 1. Distribution of samples according to gender

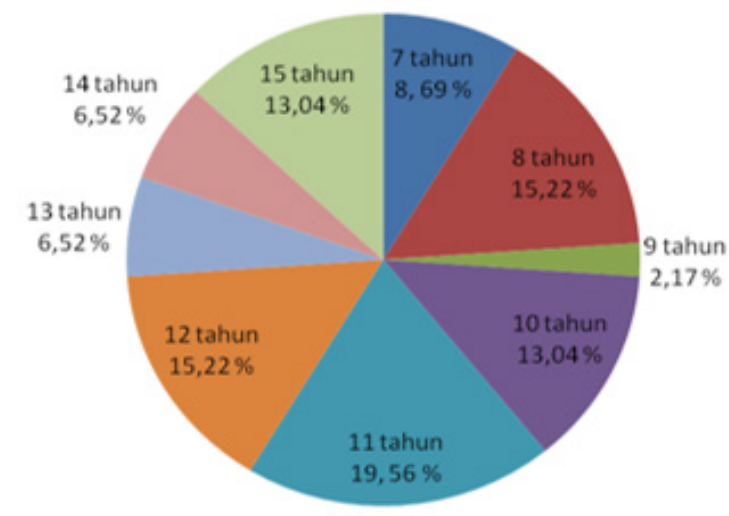

Gambar 2. Distribution of respondents according to their age 
of 46 samples were obtained consisting of 22 girls and 24 boys are shown in Figure 1.

Respondents are then categorized according to their Age. 4 children are 7 years old. 7 children

Tabel 1. Characteristic of oral habits of the respondents

\begin{tabular}{lcc}
\hline \multicolumn{1}{c}{ Information } & $\begin{array}{c}\text { Number of } \\
\text { children }(\mathrm{n}=46)\end{array}$ & Percentage \\
\hline Had oral habit & 33 & $71.74 \%$ \\
Did not have oral habit & 13 & $28.26 \%$ \\
\hline
\end{tabular}

Tabel 2. Frequency of street kids who had oral habits according the gender

\begin{tabular}{ccc}
\hline Gender & $\begin{array}{c}\text { Number of children } \\
(\mathrm{n}=33)\end{array}$ & Persentage \\
\hline Female & 15 & $45.45 \%$ \\
Male & 18 & $54.54 \%$ \\
\hline
\end{tabular}

Tabel 3. Frequency of street kids who had oral habits according the age

\begin{tabular}{ccc}
\hline Gender & $\begin{array}{c}\text { Number of children } \\
(\mathrm{n}=33)\end{array}$ & Persentage \\
\hline 7 & 3 & $9,09 \%$ \\
8 & 4 & $12,12 \%$ \\
9 & 0 & 0 \\
10 & 6 & $18,18 \%$ \\
11 & 6 & $18,18 \%$ \\
12 & 7 & $21,21 \%$ \\
13 & 2 & $6,06 \%$ \\
14 & 2 & $6,06 \%$ \\
15 & 3 & $9,09 \%$ \\
\hline
\end{tabular}

Tabel 4. Frekuensi Jenis Oral Habit yang Dimiliki Anak Jalanan

\begin{tabular}{lcc}
\hline \multicolumn{1}{c}{ Type of oral habit } & $\begin{array}{c}\text { Number of children } \\
(\mathrm{n}=46)\end{array}$ & Percentage \\
\hline Thumb sucking & 3 & $6.52 \%$ \\
Sucking or biting lips & 12 & $26.09 \%$ \\
Nail biting & 10 & $21.74 \%$ \\
Mouth breathing & 8 & $17.39 \%$ \\
\hline
\end{tabular}

Tabel 5. Distribution of Oral habits of street kids

\begin{tabular}{lcc}
\hline \multicolumn{1}{c}{ Type of oral habit } & $\begin{array}{c}\text { Number of children } \\
(\mathrm{n}=46)\end{array}$ & Percentage \\
\hline Thumb sucking & 3 & $9.09 \%$ \\
Sucking or biting lips & 12 & $36.36 \%$ \\
Nail biting & 10 & $30.30 \%$ \\
Mouth breathing & 8 & $24.24 \%$ \\
\hline
\end{tabular}

are 8 years old. 1 child is 9 years old. 6 children are 10 years old. 9 children are 11 years old. 7 children are 12 years old. 3 children are 13 years old. 3 children are 14 years old. 6 children are 15 years old (as shown in Diagram 4.2). The number of children with the age of 11 years old are the most and 9 years old are the least.

Table 1 shows that out of 46 street kids who had been examined, 33 of them had oral habits $(71.74 \%)$, while 13 of them did not have oral habits (28.26\%). The data obtained are then grouped according to the gender and age as in Table 2 and Table 3.

Based on gender, the number of male children with oral habits is more than female. A total of 15 female $(45.45 \%)$ had oral habits and 18 male $(54.54 \%)$ had oral habits.

Based on age, street kids with the age of 7 years old who have oral habits are $9.09 \%$. Street kids with the age of 8 years old who have oral habits are $12.12 \%$. Street kids with the age of 10 and 11 years old who have oral habits are $18.18 \%$. Street kids with the age of 12 years old who have oral habits are $21.21 \%$. Street kids with the age of 13 and 14 years old who have oral habits are $6.06 \%$. Street kids with the age of 15 years old who have oral habits are $9.09 \%$.

This research was conducted on 4 types of oral habits that are often done by children, namely thumb sucking, sucking or biting lips, nail biting and mouth breathing. Table 4 shows the frequency of types of oral habits possessed by 46 street kids. There are 3 children who have finger sucking habit (6.52\%). There were 12 children who had the habit of sucking or biting their nails (26.09\%). There are 10 children who have nail biting habits (21.74\%). There are 8 children who have mouth breathing habits (17.39\%).

Table 5 shows the distribution of types of oral habits by 33 street kids who have oral habits. $9.09 \%$ of street children have the habit of sucking their fingers. $42.42 \%$ of street children have the habit of sucking or biting their lips. $30.3 \%$ of street children have the habit of nail biting. $27.27 \%$ of street children have the habit of mouth breathing.

\section{DISCUSSION}

Based on the results of the study in table 1 , the percentage of the number of street kids 
in Rumah Perlindunga Anak GANK who has oral habits is quite large $(71.74 \%)$. Other studies also explain almost the same thing. Research conducted by Gildasya on street children at the Ark Foundation said $50 \%$ of street children have oral habits, as well as research conducted in Pernambuco, Brazil for children aged 5-12 years said that $60.8 \%$ of children have oral habits. Other studies explain somewhat different things, namely a lower percentage, research conducted by Eriska Riyanti and Winny Yohana states the percentage of children aged 6-12 years who have oral habits is $36.14 \%$. Another study conducted by Bhayya and Shyagali on children aged 11-13 years in Gulbarga, India said $38 \%$ of children have oral habits.

The causes of oral habit are vary. Most causes of oral habit are psychological disorders. This was shown from the results of interviews through a questionnaire explaining that as many as $72.72 \%$ of street children were scolded by their parents. Some others are not scolded by their parents but they don't get enough attention and don't live with their parents so often they feel lonely. Children aged 7-15 years which are in the stage of childhood and early adolescence really need a parent figure who can provide attention, support and love for psychological development. Children who are often scolded by parents often feel scared, anxious, insecure and lacking confidence so they feel pressured by their environment. Street children who live on the streets are not only scolded by parents, they are also often scolded by the community when they work on the street. The environment of street children does not support their psychological development. Therefore, they tend to experience psychological developmental disorders and take actions such as oral habits to compensate for their feelings.

Psychological development which includes physical, mental, social, emotional development, is influenced by internal factors such as heredity and external factors such as environment, experience. Every child follows the same pattern of development but the achievements of each child are different. Variations in this development are related to learning or experience factors, innate, and environmental factors. The result of the interaction between oneself and the environment is known as behavior. ${ }^{11}$

Based on the results of interviews using a questionnaire showed street children (39.39\%) who have oral habits tend to feel comfortable when doing these habits. Feelings of fear, anxiety, depression that initially felt tend to decrease when they do oral habits. Some others feel happy and satisfied when they do oral habits. This shows that children who perform oral habits are children's efforts to divert their feelings so that their feelings get better.

The development of oral habits can occur in both girls and boys. Based on the results of the study in table 2 , the percentage of boys and girls who have oral habits is almost the same. The percentage of boys is slightly higher than that of girls. Research conducted by Gildasya explains the same thing: the percentage of boys who have more oral habits than girls. This is caused by boys being more against their own feelings than girls so that oral habits last longer for boys. Boys and girls like to join their peers to form an emotional relationship called friendship. Girls tend to be open to their group of friends. Feelings that arise are usually shared with friends. Feeling depressed which initially felt can be reduced when they gather with his friends. Conversely, boys are usually more closed with their environment, boys tend to be ashamed to tell their feelings to a group of friends. Feelings that arise will remain in his heart so often feel depressed. Therefore, oral habits tend to stay longer in boys.

Based on the age in table 3, 12-year-old street children have the largest percentage of having oral habit $(21.21 \%)$. Research conducted by Bhayya and Shyagali shows the same thing, the percentage of the age of children who have the largest percentage of having oral habit are the age of 12 years. Children aged 6-12 years are children at school, they get various demands from parents and the surrounding environment. Children also begin to adapt outside the family environment. Not infrequently these demands create pressure on children, especially on street children. Those who should have attended school tonight

Based on the distribution of types of oral habit in table 5 , the most prevalence oral habit is sucking or biting the lip (36.36\%) followed by the habit of biting the nails, mouth breathing and thumb sucking. Children aged 7-15 years enter the period of biting and the period of change so that few children have the habit of thumb sucking. 
Children who have oral habit with a duration of more than 1 year and a frequency of more than 1 time per day show a clinical picture in accordance with the type of oral habit, they have such as protrusive maxillary anterior teeth, retinal lower anterior teeth, openbite, diastema, large overjet, deep bite, palate shape, tooth enamel attrition and mucosal conditions as well as nail and finger conditions. The level of damage clinically depends on the duration, frequency and intensity of the habit.

\section{CONCLUSION}

Oral habit frequensy were most performed in homeless children was lip sucking or biting.

\section{REFERENCES}

1. Felix R. Perlindungan Anak di Indonesia. Available from: http://regafelix.wordpress. com /2010/11/19/perlindungan-anak-diindonesia/. [Cited 22 Nov 2011). 2010.

2. Huraerah A. Child Abuse (Kekerasan terhadap anak). Bandung: Nuansa. 2007. p. 88-93.

3. Hurlock EB. Psikologi Perkembangan:Suatu Pendekatan Sepanjang Rentang Kehidupan. Jakarta: Erlangga. 2000.
4. Hoesin I. Pengertian Anak Jalanan. Pendidikan Layanan Khusus. Available from: http:// pendidikanlayanankhusus.wordpress. com/2008/10/13pengertian-anak-jalanan. [Cited Feb 2012]. 2008.

5. Gunarsa SD. Psikologi Perkembangan Anak dan Remaja. Jakarta: Gunung Mulia. 2008. p. 428.

6. Finn SB. Clinical pedodontics. $4^{\text {th }}$ ed. Philadelphia: W. B.Saunders Co. 2003. p. 370383.

7. Barberia Lucavechi T, Cárdenas D, Maroto M. An atypical lingual lesion resulting from the unhealthy habit of sucking the lower lip: clinical case study. J Clinical Pediatric Dentistry 2006;30(4):280-2.

8. Moyers ER. Handbook of orthodontics $4^{\text {th }}$ ed. London: Year Book Medical Publisher. 1988. p. 152-6.

9. Muthu, Sivakumar. Pediatric Dentistry: Principles and Practice. India: Elsevier. 2009. p. 321-7.

10. Notoatmodjo S. Metodologi Penelitian Kesehatan. Jakarta: PT. Rineka Cipta. 2010. p. 35-6.

11. Gunarsa SD. Psikologi Praktis:Anak, Remaja dan Keluarga. Jakarta: Gunung Mulia. 2004. p. 1-16. 